\title{
Six-year incidence and some features of cases of brachial plexus injury in a tertiary referral center
}

\section{Tersiyer merkezde altı yıllık brakial pleksus hasarı olgularinın insidansı ve bazı klinik özellikleri}

\author{
Meryem Eken1, Mehmet Çınarl, Taylan Şenol2, Enis Özkayal1, Ateş Karatekel \\ 1Zeynep Kamil Women and Children's Health Training and Research Hospital, Clinic of Obstetrics and Gynecology, İstanbul, Turkey \\ 2Zekai Tahir Maternity and Womens Health Training and Research Hospital, Clinic of Obstetrics and Gynecology, Ankara, Turkey
}

\begin{abstract}
Objective: To present some features and incidence of cases of brachial plexus injury in deliveries at the Department of Obstetrics and Gynecology of Zeynep Kamil Maternity and Children's Training and Research Hospital, from January 2010 through December 2014.

Materials and Methods: In total, 38.896 deliveries in the Department of Obstetrics and Gynecology of Zeynep Kamil Maternity and Children's Training and Research Hospital, from January 2010 through December 2014 were screened from a prospectively collected database. We recorded gravidity, parity, body mass index, maternal diabetes, labor induction, gestational age at delivery, operative deliveries, malpresentations, prolonged second stage of deliveries, shoulder dystocies, clavicle and humerus fructures, estimated fetal weight, biparietal diameter, abdominal circumference, femur length, fetal sex, route of delivery, maternal age, and fetal anomalies.

Results: There were 28 (72/100.000) cases of brachial plexus injury among 38.896 deliveries. In the 6-year study period, there were 18.363 deliveries via c-section, whereas 20.533 were vaginal deliveries.

Conclusion: Sonographic fetal weight estimation and clinical examination performed by experienced obstetricians, and active appropriate management of shoulder dystocias seemed to attenuate the incidence of brachial plexus injury in the at risk population in our tertiary referral center. J Turk Soc Obstet Gynecol 2015;2:71-4
\end{abstract}

Key Words: Brachial plexus injury, shoulder dystocia, vaginal delivery

Özet

Amaç: Ocak 2010-Aralık 2014 yılları arasında Zeynep Kamil Kadın ve Çocuk Hastalıkları Eğitim Araştırma Hastanesi, Kadın Doğum bölümünde görülen brakial pleksus hasarı olgularının insidansını ve bazı klinik özelliklerini sunmaktır.

Gereç ve Yöntemler: Ocak 2010-Aralık 2014 yılları arasında Zeynep Kamil Kadın ve Çocuk Hastalıkları Eğitim Araştırma Hastanesi, Kadın Doğum bölümündeki 38,896 doğum prospektif olarak kayda alınan veritabanından tarandı. Tüm doğumlar içinde Erb Duchenne, Klumpke felci ve brakial pleksus hasarı olguları ayırt edildi. Tüm olgular için gravida, parite, vücut kitle indeksi, maternal diabet, doğum indüksiyonu, doğum haftası, operatif doğumlar, malprezentasyonlar, doğumun 2. evresinin uzaması, omuz distosisi, klavikula, humerus kırıkları, tahmini fetal ağırlık, biparyatal çap, karın çevresi, femur uzunluğu, fetal cinsiyet, doğum şekli, maternal yaş ve fetal anomaliler not edildi.

Bulgular: Altı yıl boyunca 18,363'ü sezaryen, 20,533'ü vajinal olan toplam 38,896 doğum arasında 28 (72/100,000) olguda brakiyal pleksus hasarı gözlendi.

Sonuç: Sonografik fetal ağırlık tahmini, tecrübeli klinisyen tarafından yapılan klinik muayene ve omuz distosisinin uygun yönetimi, riskli popülasyonun takip edildiği tersiyer merkezde brakiyal pleksus hasarı insidansını azaltmış görünmektedir. J Turk Soc Obstet Gynecol 2015;2:71-4

Anahtar Kelimeler: Brakiyal pleksus hasarı, omuz distosisi, vajinal doğum

\section{Introduction}

Shoulder dystocia is an important cause of neonatal and maternal injury, the incidence of which is reported to be between $0.6-1.4 \%$ in vaginal births(1). Shoulder dystocia may result in a major neonatal injuries including brachial plexus palsies, fractures of the clavicle and humerus, hypoxic ischemic encephalopathy, and in rare cases, neonatal death(1).

To overcome this problem, prophylactic ceserean section and health personnel training strategies have been tried for the acute management of shoulder dystocia. Several risk factors have been identified for the selection of appropriate candidates for

Address for Correspondence/Yazıșma Adresi: Enis Özkaya, MD,

Zeynep Kamil Women and Children's Health Training and Research Hospital, Clinic of Obstetrics and Gynecology, İstanbul, Turkey

Phone: +90 5054742459 E-mail: enozkaya1979@gmail.com

Received /Geliş Tarihi : 04.05.2015

Accepted/Kabul Tarihi : 12.06.2015 
prohylactic ceserean section; however, none of them reached sufficient sensitivity or specificity(2-4). Therefore, to prevent a single case of permanant neonatal injury, very large numbers of prophylactic cesareans are needed, which may result in severe maternal morbidity $(4,5)$. Although training for acute management of shoulder dystocia has been suggested, there has been little objective evidence that this training impacts neonatal and maternal injuries(5). The rate of neonatal brachial plexus injury in the United States and other countries is comparable: 1.5 vs. 1.3 per 1000 total births, respectively. Most of the antepartum or intrapartum factors cannot be used as a guide for selecting patients at high risk for shoulder dystocia with or without brachial plexus injury(6). Previous data showed sequential use of vacuum and forceps to be risk a factor for both neonatal and maternal injury(7). Data suggest that the McRoberts' maneuver is adequately successful at relieving shoulder dystocia in the majority of cases and may be associated with decreased morbidity compared with other maneuvers. As a consequence, the McRoberts' maneuver is recommended as the initial technique for disimpaction of the anterior shoulder(8).

The aim of this study was to present some features and incidence of cases of brachial plexus injury in deliveries at the Department of Obstetrics and Gynecology of Zeynep Kamil Maternity and Children's Training and Research Hospital, from January 2010 through December 2014.

\section{Materials and Methods}

At the Zeynep Kamil Women and Children's Health Training and Research Hospital, prospectively collected records of labor and delivery, nursery, and neonatal intensive care unit were reviewed and identified from the computer database of all deliveries that included details of the labor, all cases of Erb's/ Duchenne and Klumpke's palsies and brachial plexus injury confirmed by a pediatric neurologist's examination. Among all cases of brachial plexus injury, we recorded gravidity, parity, body mass index, maternal diabetes, labor induction, gestational age at delivery, operative deliveries, malpresentations, prolonged second stage of deliveries, shoulder dystocias, clavicle and humerus fructures, estimated fetal weight, biparietal diameter, abdominal circumference, femur length, fetal sex, route of delivery, maternal age, and fetal anomalies. After delivery of the fetal head, shoulder dystocia was considered in cases when there was need for additional obstetric maneuvers in addition to gentle downward traction. Maneuvers used after unsuccessful head traction were identified as follows: McRoberts maneuver, suprapubic pressure, Rubin maneuver, delivery of the posterior shoulder, Woods corkscrew maneuver, Gaskin maneuver (delivery in the maternal knee-chest position), Zavanelli maneuver, and fundal pressure. Prolonged second stage of labor was defined as longer than $2 \mathrm{~h}$ and was extended to more than $3 \mathrm{~h}$ when regional analgesia was used in nulliparas. For multiparas, $1 \mathrm{~h}$ was the limit, but was extended to $2 \mathrm{~h}$ with regional analgesia based on deviations from Friedman's curve
(Macrosomia was defined as a birth weight equal to or more than $4000 \mathrm{~g}^{(9)}$. Estimated fetal weight deviation was defined as the difference from expected fetal weight for gestational age, expressed as a percentage)(estimated weight) expected weight $/($ expected weight $) * 100)(10)$. Body mass index (BMI) was calculated (initial weight/height ${ }^{2}\left(\mathrm{~kg} / \mathrm{m}^{2}\right)$. Excessive weight gain during pregnancy was defined as weight gain above 16 $\mathrm{kg}$ between the first visit and delivery. Head circumference was measured on a transverse view of the fetal head in an axial plane at the level at which the continuous midline echo was broken by the cavum septi pellucidi in the anterior third and derived from measurement of the occipitofrontal diameter and biparietal diameter(11). Abdominal circumference was measured on a transverse plane, just above the level of the cord insertion and computed from orthogonal diameters(12). To measure femur length, a sonographic plane was obtained including the entire femoral diaphysis, with both ends clearly visible and at an angle of $<45^{\circ}$ to the horizontal(13). Estimated fetal weight was calculated in all cases using the following formula of Hadlock et al.(14). Data was entered into SPSS version 15. Some clinical and demographic characteristics of the study population were summarized using descriptive statistics. Chi-square cross tables were used to summarize data of categorical variables. $\mathrm{P}<0.05$ was accepted as statistically significant.

\section{Results}

There were $28(72 / 100.000)$ cases of brahial plexus injury among 38.896 deliveries. Some $18.363(47.21 \%)$ of the deliveries were via c-section, whereas there were 20.533 vaginal deliveries in the 6-year study period. Some demographic and clinical parameters of the cases of brachial plexus injury are summarized in Table 1. The data of women who were grouped according to the WHO BMI classification are summarized in Table 2. Some features of the groups summarized in Table 3.

\section{Discussion}

In this article, we wanted to point out some clinical characteristics of obstetric cases of brachial plexus injury that occurred in our tertiary referral center. Analyses of the data generated from 2010 through 2014 showed that the incidence of obstetric brachial plexus injury was lower our center, which is thought to be the result of increased awareness, experience,

Table 1. Maternal demographic characteristics

\begin{tabular}{|lll|}
\hline Age (years) & Mean \pm SD & Min-Max \\
\hline Gravidity & $28.11 \pm 6.63$ & $18-42$ \\
\hline Parity & $2.50 \pm 1.29$ & $1-6$ \\
\hline Pregnancy weeks & $1.18 \pm 0.98$ & $0-4$ \\
\hline BMI & $39.89 \pm 1.06$ & $38-42$ \\
\hline BMI: Body mass index & $32.0 \pm 5.61$ & $24.2-46.8$ \\
\hline
\end{tabular}


and training. Another explanation for this decrement is the increasing rates of ceserean section that has resulted from the increased awareness of parents of the responsibilities of health workers, which can lead to litigation. In the literature, the incidence of brachial plexus injury has been reported to be 1-2 per 1000 births(15). The incidence of obstetric brachial plexus injury in our study population was 0.72 per 1000 births including both vaginal and ceserean deliveries. Shoulder dystocia and brachial plexus injury have an unpredictable nature. A study on risk factors for brachial plexus injury showed that shoulder dystocia, macrosomia, labor dystocia, vacuum delivery and vaginal breech deliveries were significant risk factors for neonatal brachial plexus paralysis. The study found no association between maternal characteristics such as

Table 2. Fetal and neonatal characteristics

\begin{tabular}{|lll|}
\hline & Mean \pm SD & Min-Max \\
\hline BPD (mm) & $92.39 \pm 3.76$ & $85-98$ \\
\hline AC (mm) & $355.79 \pm 12.9$ & $327-382$ \\
\hline EFW (gr) & $3662.36 \pm 292.1$ & $3160-4300$ \\
\hline Birth weight (gr) & $3892.14 \pm 427.7$ & $3240-4830$ \\
\hline Newborn head circumference (cm) & $35.0 \pm 0.87$ & $33-37$ \\
\hline Newborn height (cm) & $50.56 \pm 1.18$ & $33-37$ \\
\hline Apgar score (1. minute) & $7.46 \pm 120$ & $3-9$ \\
\hline Apgar score (5. minute) & $8.86 \pm 0.65$ & $8-10$ \\
\hline BPD: Biparietal diameter, AC: Abdominal circumference, EFW: Estimated fetal weight
\end{tabular}

obesity and diabetes. The authors concluded that despite the improved knowledge of risk factors associated with brachial plexus paralysis, unfortunately, this condition cannot be predicted or prevented(16). Moreover, other data showed no reliable factors associated with the brachial plexus palsy(17). The overall incidence of neonatal brachial plexus palsy, both transient and persistent impairment, was reported to be 1.5 per 1000 total births in the American Congress Obstetricians Gynecologists bulletin in 2014. Due to the changes of health policies in Turkey and with increasing health litigations since 2002, ceserean section rates have started to increase. The increased rate of ceserean deliveries $(47.21 \%)$ is thought to be the major determinant of this low incidence of injury in our population, but we should not disregard the role of trained health workers and well-conducted maneuvers during shoulder dystocia management. In a previous study, direct fetal manipulation techniques used to overcome shoulder dystocia were not found to be associated with an increased rate of brachial plexus injury(18). A study conducted in 1997 concluded that the McRoberts' maneuver was associated with a significant degree of success in relieving shoulder dystocia and may be associated with decreased morbidity compared with other maneuvers(19). Although the Cochrane review concluded that prophylactic maneuvers should not be used to prevent shoulder dystocia, if a recognizable risk factor for shoulder distocia is present in our institution, a prophylactic McRoberts maneuver is used most of the time(20). When the role of sonography is considered in the prevention neonatal injury, a review published in 2004 reported that the true value

Table 3. Some characteristics of groups established relative to body mass index

\begin{tabular}{|c|c|c|c|c|c|}
\hline & $\begin{array}{l}\text { Normal weight }(\mathrm{n}=3) \\
\text { Frequency } \%(\mathrm{n})\end{array}$ & $\begin{array}{l}\text { Preobesity }(n=6) \\
\text { Frequency } \%(n)\end{array}$ & $\begin{array}{l}\text { Obesity class } 1(n=14) \\
\text { Frequency } \%(n)\end{array}$ & $\begin{array}{l}\text { Obesity class } 2(n=2) \\
\text { Frequency } \%(n)\end{array}$ & $\begin{array}{l}\text { Obesity class } 3(n=3) \\
\text { Frequency } \%(n)\end{array}$ \\
\hline Preeclampsia & - & - & $3.57(1)$ & - & $7.14(2)$ \\
\hline CPD & - & - & - & - & $3.57(1)$ \\
\hline $\begin{array}{l}\text { Vacuum } \\
\text { extraction }\end{array}$ & $3.57(1)$ & $3.57(1)$ & $3.57(1)$ & - & - \\
\hline $\begin{array}{l}\text { Breech } \\
\text { presentation }\end{array}$ & - & - & $3.57(1)$ & - & - \\
\hline $\begin{array}{l}\text { Prolongation } 2^{\text {th }} \\
\text { stage of labor }\end{array}$ & $3.57(1)$ & - & $7.14(2)$ & - & - \\
\hline Shoulder dystocia & $3.57(1)$ & $17.85(5)$ & $28.5(8)$ & $7.14(2)$ & $7.14(2)$ \\
\hline Clavicula injury & $3.57(1)$ & - & $7.14(2)$ & - & - \\
\hline Vaginal delivery & $10.71(3)$ & $21.42(6)$ & $42.8(12)$ & $7.14(2)$ & $3.57(1)$ \\
\hline Cesarian delivery & - & - & $7.14(2)$ & - & $7.14(2)$ \\
\hline Diabetes & - & $10.71(3)$ & $21.42(6)$ & - & $14.28(4)$ \\
\hline Hypertension & $7.14(2)$ & - & $14.28(4)$ & $3.57(1)$ & $14.28(4)$ \\
\hline \multicolumn{6}{|l|}{ Fetal sex } \\
\hline Male & $7.14(2)$ & $10.71(3)$ & $25(7)$ & - & $7.14(2)$ \\
\hline Female & $3.57(1)$ & $10.71(3)$ & $25(7)$ & $7.14(2)$ & $3.57(1)$ \\
\hline
\end{tabular}


of ultrasonography in the management of fetal macrosomia may be its ability to rule out the diagnosis. Ultrasound-derived fetal weight estimates alone are not sensitive or specific enough to determine a route of delivery(21). However, since then the quality of sonography equipment and experience in this area has greatly developed. A recently published study concluded that the impact of diabetes as a risk factor has been minimized by the means of improved screening and treatment, and antenatal sonography was thought to be a promising tool; however, its predictive value is still too low to be used alone(22). In conclusion, sonographic fetal weight estimation and clinical examination performed by experienced obstetricians, and active appropriate management of shoulder dystocias with increased rates of ceserean section seemed to attenuate the incidence of brachial plexus injury in the at risk population at our tertiary referral center.

Ethics Committee Approval: Approved from local ethic committee.

Informed Consent: It was taken.

Concept: Meryem Eken, Ateş Karateke

Design: Meryem Eken, Enis Özkaya, Mehmet Çınar

Data Collection or Processing: Taylan Şenol, Meryem Eken, Enis Özkaya

Analysis or Interpretation: Enis Özkaya, Meryem Eken

Literature Search: Enis Özkaya, Meryem Eken, Mehmet

Çınar, Taylan Şenol

Writing: Meryem Eken, Ateş Karateke

Peer-review: Externally peer-reviewed.

Conflict of Interest: No conflict of interest was declared by the authors.

Financial Disclosure: The authors declared that this study has received no financial support.

\section{References}

1. ACOG Committee on Practice Bulletins-Gynecology, The American College of Obstetrician and Gynecologists. ACOG practice bulletin clinical management guidelines for obstetrician-gynecologists. Number 40, november 2002. Obstet Gynecol 2002;100:1045-50.

2. Mansor A, Arumugam K, Omar SZ. Macrosomia is the only reliable predictor of shoulder dystocia in babies weighing $3.5 \mathrm{~kg}$ or more. Eur J Obstet Gynecol Reprod Biol 2010;149:44-6.

3. Mazouni C, Porcu G, Cohen-Solal E, Heckenroth H, Guidicelli B, Bonnier $\mathrm{P}$, et al. Maternal and anthropomorphic risk factors for shoulder dystocia. Acta Obstet Gynecol Scand 2006;85:567-70.

4. Hankins GD, Clark SM, Munn MB. Cesarean section on request at 39 weeks: impact on shoulder dystocia, fetal trauma, neonatal encephalopathy, and intrauterine fetal demise. Semin Perinatol 2006;30:276-87.
5. MacKenzie IZ, Shah M, Lean K, Dutton S, Newdick H, Tucker DE. Management of shoulder dystocia: trends in incidence and maternal and neonatal morbidity. Obstet Gynecol 2007;110:1059-68.

6. Chauhan SP, Christian B, Gherman RB, Magann EF, Kaluser CK, Morrison JC. Shoulder dystocia without versus with brachial plexus injury: a casecontrol study. J Matern Fetal Neonatal Med 2007;20:313-7.

7. Gardella C, Taylor M, Benedetti T, Hitti J, Critchlow C. The effect of sequential use of vacuum and forceps for assisted vaginal delivery on neonatal and maternal outcomes. Am J Obstet Gynecol 2001;185:896-902.

8. Monier I. Shoulder dystocia, an analysis at hôpital Foch of Suresnes. J Gynecol Obstet Biol Reprod (Paris) 2011;40:50-7.

9. Friedman E. Evolution of graphic analysis of labor. Am J Obstet Gynecol 1978;132:824-7.

10. Marsal K, Persson PH, Larsen T, Lilja H, Selbing A, Sultan B. Intrauterine growth curves based on ultrasonically estimated foetal weights. Acta Paediatr 1996;85:843-8.

11. Fadigas C, Saiid Y, Gonzalez R, Poon LC, Nicolaides KH. Prediction of small-for-gestational-age neonates: screening by fetal biometry at 35-37 weeks. Ultrasound Obstet Gynecol 2015;45:559-65.

12. Wu M, Shao G, Zhang F, Ruan Z, Xu P, Ding H. Estimation of fetal weight by ultrasonic examination. Int J Clin Exp Med 2015;8:540-5.

13. Salomon LJ, Duyme M, Crequat J, Brodaty G, Talmant C, Fries N, et al. French fetal biometry: Reference equations and comparison with other charts. Ultrasound Obstet Gynecol 2006;28:193-8.

14. Hadlock FP, Harrist RB, Sharman RS, Deter RL, Park SK. Estimation of fetal weight with the use of head, body, and femur measurements-a prospective study. Am J Obstet Gynecol 1985;151:333-7.

15. Chauhan SP, Blackwell SB, Ananth CV. Neonatal brachial plexus palsy: Incidence, prevalence, and temporal trends. Semin Perinatol 2014:38:210-8.

16. Okby R, Sheiner E. Risk factors for neonatal brachial plexus paralysis. Arch Gynecol Obstet 2012;286:333-6.

17. Ouzounian JG, Korst LM, Miller DA, Lee RH. Brachial plexus palsy and shoulder dystocia: obstetric risk factors remain elusive. Am J Perinatol 2013;30:303-8.

18. Gherman RB, Ouzounian JG, Goodwin TM. Obstetric maneuvers for shoulder dystocia and associated fetal morbidity. Am J Obstet Gynecol 1998;178:1126-30.

19. Gherman RB, Goodwin TM, Souter I, Neumann K, Ouzounian JG, Paul RH. The McRoberts' maneuver for the alleviation of shoulder dystocia: How successful is it? Am J Obstet Gynecol 1997;176:656-61.

20. Athukorala C, Middleton P, Crowther CA. Intrapartum interventions for preventing shoulder dystocia. Cochrane Database Syst Rev 2006:CD005543.

21. Ben-Haroush A, Yogev Y, Hod M. Fetal weight estimation in diabetic pregnancies and suspected fetal macrosomia. J Perinat Med 2004;32:113-21.

22. Parantainen J, Palomäki O, Talola N, Uotila J. Clinical and sonographic risk factors and complications of shoulder dystocia-a case-control study with parity and gestational age matched controls. Eur J Obstet Gynecol Reprod Biol 2014;177:110-4. 